\title{
Different Substrates and Container Volumes in the Emergence and Ministumps Formation of Physalis peruviana L.
}

\author{
Jeniffer Ribeiro de Oliveira ${ }^{1}$, Mariana Alexandre Alves Amourim ${ }^{1}$, Weslley do Rosário Santana ${ }^{1}$, \\ João Vitor Garcia Silva ${ }^{1}$, Vinicius de Souza Oliveira ${ }^{2}$, Érica Duarte Silva ${ }^{1}$, Jalille Amim Altoé ${ }^{\text {, }}$ \\ Alex Campanharo ${ }^{1}$, Mayara Nascimento Santos ${ }^{3}$, Joabe Martins de Souza ${ }^{1}$, Bruna Alves Salomão, \\ Aclécia Gonçalves Batista ${ }^{1}$, Luan Carlos Ferreira Angeli ${ }^{1}$, Gleison Oliosi ${ }^{1}$, André Cayô Cavalcanti ${ }^{1}$, \\ Alex Silva Lima ${ }^{1} \&$ Hugo Rebonato Pelegrini ${ }^{1}$ \\ ${ }^{1}$ Federal University of Espírito Santo, São Mateus, ES, Brazil \\ ${ }^{2}$ Federal University of Espírito Santo, Alegre, ES, Brazil \\ ${ }^{3}$ Federal University of Vila Velha, ES, Brazil \\ Correspondence: Jeniffer Ribeiro de Oliveira, Federal University of Espírito Santo, São Mateus, ES, Brazil. \\ E-mail: jeniffer.jr1994@gmail.com
}

Received: August 6, 2020

doi:10.5539/jas.v12n12p114
Accepted: October 13, 2020

Online Published: November 15, 2020

URL: https://doi.org/10.5539/jas.v12n12p114

\begin{abstract}
To obtain quality seedlings, it is necessary to use good production techniques. Important factors include the container and the form of propagation. Therefore, the objective of this work was to evaluate the influence of two substrates and container volumes on the emergence and formation of Physalis peruviana L. mini-stumps. The work was carried out from September to November 2019, in a greenhouse belonging to the Federal University Network of the Holy Spirit. The design used was completely randomized, in a factorial scheme with the combination of three containers $(\mathrm{R} 1=$ tube with a volume of $50 \mathrm{ml} ; \mathrm{R} 2=$ tube with a volume of $280 \mathrm{ml}$ and $\mathrm{R} 3=$ plastic cups with a volume of $500 \mathrm{ml})$ and two substrates $\left(\mathrm{S} 1=\right.$ Bioplant $^{\circledR}$ and $\mathrm{S} 2=$ Provaso $^{\circledR}+$ soil $\left.^{1: 1}\right)$, totaling six treatments, four replications, six plants per experimental unit and 144 plants. After 90 days of experiment, it is recommended for a better emergence and emission of the shoots of Physalis peruviana L. the use of the volume of $280 \mathrm{ml}$, combined with the substrate Provaso $^{\circledR}+$ soil.
\end{abstract}

Keywords: sprouting, vegetative propagation, emergence speed

\section{Introduction}

The genus Physalis contains several species that produce edible fruits with a sour and sweet flavor (Vargas-Ponce et al., 2016). Colombia is the largest producer of physalis, followed by South Africa (Muniz er al., 2015). Physalis peruviana L. is an exotic Andean fruit with high nutritional value and attractive medicinal properties (Puente et al., 2011), has high added value and can be used from the root to the fruit itself. The roots and leaves are rich in medicinal properties used in pharmacology. The fruit, sweet and with a good content of vitamins A and C, in addition to Fe, $\mathrm{P}$ and fibers, is widely used in jellies, sweets, juices and ice creams (Muniz et al., 2014).

The cultivation of physalis is considered simple cultivation, and most of the management used in its cultivation is still in accordance with the culture of the tomato (Ianckievicz et al., 2013). The commercial cultivation of physalis fruits in Brazil is not properly explored, mainly due to the scarcity of research results available to farmers (Muniz et al., 2014). However, the production of physalis has been increasing in the country every year, with productions of 2 to $3 \mathrm{t}_{\text {year }}{ }^{-1}$ of fruit being reported, being commercialized mainly in large markets at high prices (Fischer et al., 2014). Increasing crop yields is one of the goals pursued by research in the search for greater efficiency in the agricultural production process.

The substrate plays an important role in plant growth, having to guarantee, through its solid phase, the growth of the aerial part and the development of the root system (Mendoça et al., 2014). Thus, one of the points of importance to be defined in the search for obtaining good quality seedlings, in addition to seeds with high physiological potential, is the definition of a more suitable substrate for seedling formation, as the substrate has great influence on the process germination, it must have good structure, aeration, water retention capacity, absence of pest and pathogen infestation, among others, favoring seed germination (Kuhn et al., 2012). 
The propagation of physalis at the commercial level occurs sexually, through the use of seeds taken from ripe fruits $(85-90 \%)$ (Sbrussi et al., 2014). However, this is not the only method, as it can be propagated for cutting and tissue culture (Rufato et al., 2008). Among the techniques of vegetative propagation, mini-cuttings currently deserve to be highlighted, to the detriment of cuttings, presenting numerous advantages, such as the faster obtaining of seedlings due to the youth of the raw material, greater control of operational conditions, collection of shoots and adventitious rooting (Alfenas et al., 2009). The technique consists in the adventitious rooting of minicuttings produced in mini-stumps, maintained in a clonal mini-garden system (Xavier et al., 2013). Mini-stumps are the source of shoots (mini-cuttings) and can originate from seminal material (seedlings), from conventional cuttings or from micropropagation (in these they are usually called mini-stems).

In this context, the objective of this work was to evaluate the effect of different volumes of containers combined with different substrates on the initial growth of seedlings and on the formation of mini-stumps to obtain buds that may give rise to clonal seedlings by the minicutting process of Physalis peruviana $\mathrm{L}$.

\section{Method}

The work was carried out between the months of September and November 2019, in a greenhouse located at the Experimental Farm, at the Federal University of Espírito Santo, Campus of the North University Center of Espírito Santo (CEUNES).

The seeds of the species Physalis peruviana L. were obtained from fruits bought in local stores in the city of São Mateus-ES. Seed processing was carried out in May 2019, the fruits were pulped, the seeds removed from the pulp, packed on paper and kept in the laboratory, at room temperature, for 24 hours, in order to eliminate excess moisture. Then, the seeds were stored in a paper bag until the moment of sowing.

The microclimate conditions of the greenhouse were controlled at $28 \pm 2{ }^{\circ} \mathrm{C}$ and a relative humidity of $75 \pm 5 \%$. A completely randomized design was used, in a factorial scheme with the combination of three containers $(\mathrm{R} 1=$ tube with a volume of $50 \mathrm{ml}$; R2 = Tube with a volume of $280 \mathrm{ml}$ and R3 = disposable plastic cups with a volume of $500 \mathrm{ml})$ and two substrates $\left(\mathrm{S} 1=\right.$ Bioplant $^{\circledR}$ and $\mathrm{S} 2=$ Provaso $^{\circledR}+$ soil in volumetric proportion 1:1) in a total of six treatments and four repetitions, totaling 24 experimental units. Each experimental unit consisted of six containers with one plant, totaling 144 plants. The soil used was taken from the Experimental Farm of the Federal University of Espírito Santo (UFES/CEUNES).

The Provaso ${ }^{\circledR}$ substrate is composed of sugarcane bagasse, peat, limestone, class A agroindustrial organic waste, manure and chicken litter, ash and vegetable cake, rich in organic matter, developed for soil material from different cultures. And a product with the physical characteristics and ideal areas to increase the CTC of the soil, providing greater microbiological activity. Ready for planting and maintaining crops, such as fruit trees (orchards), vegetables in general, shrubs, vegetation cover, palms and ornamental trees (Provaso, 2020). The Bioplant ${ }^{B}$ substrate consists of sphagnum peat, coconut fiber, rice husks, pine nuts, vermiculite and nutrients. The mixture of these products, in a specific way, results in a perfect substrate for any culture, vegetables, sugar cane, forestry, potatoes and fruits (Bioplant, 2020).

Sowing was carried out on September 24, 2019, with two seeds per container at a depth of $2 \mathrm{~cm}$. After germination, the plants were thinned, leaving only the most vigorous per container. Weeds were manually removed daily. The irrigation system adopted in the experiment was the sprinkler, being carried out 3 times a day for 6 minutes each.

The count of emerged seedlings was performed daily, at the same time, from the seventh to the twenty-eighth day after sowing, germinating normal seedlings, with all normal structures, according to the recommendations of the Seed Analysis Regulation (Brasil, 2009). The variables analyzed were: percentage of emergency (\%), emergency speed index (IVE), mean emergency time (TME), shoot length (CPA) and percentage of sprouting emissions (\% EB).

The pruning of the apex of the seedlings to obtain the mini-stumps was carried out 45 days after sowing, at a height of about $10 \mathrm{~cm}$ from the collection zone, this procedure being used to stimulate the formation of sprouts by breaking the apical dominance. The shoot length was evaluated at 15,30 and 45 days after germination to verify the viability of the treatments for the mini-cutting process. Two treatments (R1S1 and R1S2, both composed of the $50 \mathrm{ml}$ container associated with the substrates Bioplant ${ }^{\mathbb{B}}$ and Provaso ${ }^{\mathbb{R}}+$ soil) proved to be unfeasible to perform the technique, as they did not reach a height close to that recommended for pruning during the period pre-established. which is between 10 and $15 \mathrm{~cm}$ high (Xavier et al., 2013), for this reason, the other four treatments that reached an adequate height were maintained in this evaluation: R2S1, R2S2, R3S1 and R3S2, consisting of 280 and Containers of $500 \mathrm{ml}$ associated with Bioplant ${ }^{\mathbb{R}}$ and Provaso ${ }^{\mathbb{R}}+$ soil substrates. 
At 7 and 15 days after pruning, collection was performed to count sprouts by seedling, in order to obtain a percentage per treatment. The data were subjected to analysis of variance (ANOVA) and the means were compared by the Tukey test, at the level of $1 \%$ significance by the ASSISTAT software (Silva \& Azevedo, 2016).

\section{Results and Discussion}

Figure 1 shows the emergency percentage values. Where treatments containing Provaso ${ }^{\circledR}+$ soil independent of the container used showed $100 \%$ emergence, in contrast treatments containing Bioplant ${ }^{\circledR}$ showed lower emergence percentages. One explanation for this result is the fact that the Bioplant ${ }^{\circledR}$ substrate has a basic composition of coconut fiber, which can cause water loss and seed germination, according to Carvalho et al. (2013), the same author also reinforces that the availability of water in the substrate is fundamental for survival and, consequently, the formation of seedlings from vegetative and seed propagation.

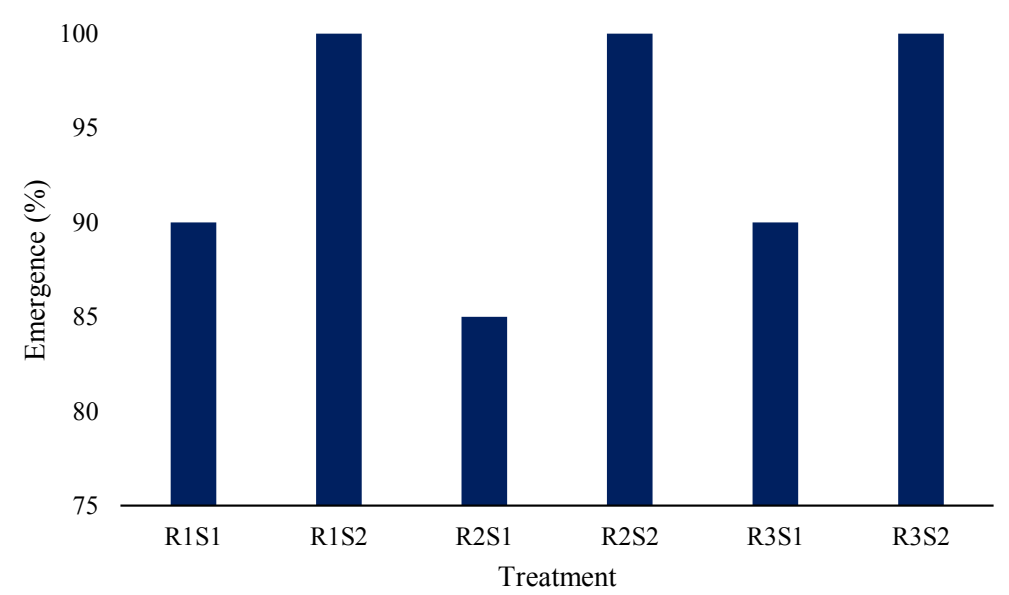

Figure 1. Percentage of emergence of treatments with Physalis peruviana L. according to different volumes of containers and substrates

In similar work Santos et al. (2017) found no differences in the percentage of emergence between the substrates tested for cherry tomatoes. The same was reported by Kuhn et al. (2012) with Physalis peruviana L., in which ripe fruit seeds had maximum emergence in peat + Provaso $^{\circledR}$ substrate, however, it was not different from other studies. When analyzing the emergency speed index and the average emergency time shown in Table 1, differences are also observed. The best percentages of emergence speed and mean emergence time were obtained in the volumes of 280 and $500 \mathrm{ml}$ and substrate composed by Provaso ${ }^{\circledR}+$ soil, showing that the higher the volume, the better the result. A similar result was found by Santos (2019), who also works with different substrates and containers in the production of Physalis peruviana L. seedlings, found that the largest volume tested (400 $\mathrm{ml})$ had a better emergence rate.

Table 1. Emergence speed index (IVE) and mean emergence time (TME) of Physalis peruviana L. seedlings according to different volumes of containers and substrates

\begin{tabular}{lll}
\hline & IVE & TME \\
\hline Containers $(\mathrm{ml})$ & & \\
50 & $2.13 \mathrm{~b}$ & $10.70 \mathrm{~b}$ \\
280 & $2.35 \mathrm{ab}$ & $10.37 \mathrm{ab}$ \\
500 & $2.46 \mathrm{a}$ & $10.11 \mathrm{a}$ \\
Substrate & & \\
Bioplant & $2.14 \mathrm{~b}$ & $10.59 \mathrm{~b}$ \\
Provaso + soil & $2.36 \mathrm{a}$ & $10.20 \mathrm{a}$ \\
CV $(\%)$ & 10.67 & 4.03 \\
\hline
\end{tabular}

Note. Averages followed by the same lowercase letter in the columns, do not differ statistically from each other, by the Tukey test at the level of $1 \%$ probability. 
Almeida et al. (2017) working with the same substrates of the present work for the production of little pepper seedlings, obtained similar results, as they found higher emergence speed indexes for the treatments with Provaso ${ }^{\circledR}$ and lower for the Bioplant ${ }^{\circledR}$ substrate.

Significant interaction was detected between the factors of pool volume and type of substrate for the variable shoot length, Table 2 significant differences both in the comparison of the volumes of and the containers in the substrates, the greater the volume of the container the greater the length of the aerial part. The best substrate was Provaso ${ }^{\circledR}$ with the treatments $280 \mathrm{ml}$ tubes and Provaso ${ }^{\circledR}+$ soil and $500 \mathrm{ml}$ cups and Provaso ${ }^{\circledR}+$ soil being the best results for this analyzed characteristic.

In agreement with the present work in an experiment carried out for the production of Physalis peruviana $\mathrm{L}$. seedlings in different substrates and containers, Santos (2019), found that the highest plant height occurred in the pool with the largest volume $400 \mathrm{~cm}^{3}$. The lower plant height grown in the $50 \mathrm{~cm}^{3}$ pool is probably due to the lower volume of substrate due to the limited space available, restricting the expansion of the root system, which consequently results in low nutrient availability, making plant development difficult. Costa et al. (2011) and Oliveira et al. (2011) working with the production of eggplant and tomato seedlings respectively, also found that the volume of the pool has a direct relationship with the height of the plants, since the seedlings that had the highest heights were grown in the largest containers.

Table 2. Shoot length (CPA) of Physalis peruviana L. seedlings according to different volumes of containers and substrates

\begin{tabular}{lll}
\hline \multirow{2}{*}{ Container $(\mathrm{ml})$} & \multicolumn{2}{c}{ Substrate } \\
\cline { 2 - 3 } & Bioplant $^{\mathbb{B}}$ & Provaso $^{\mathbb{B}}+$ soil \\
\hline 50 & $3.64 \mathrm{bB}$ & $5.22 \mathrm{cA}$ \\
500 & $10.62 \mathrm{aB}$ & $11.18 \mathrm{bA}$ \\
\hline CV $(\%)$ & $10.95 \mathrm{aB}$ & $15.16 \mathrm{aA}$ \\
\hline & 9.23 & \\
\hline
\end{tabular}

Note. Means followed by the same uppercase letter in the lines and lowercase in the columns, do not differ statistically from each other, by the Tukey test, at the level of $1 \%$ probability.

Paixão et al. (2019) when analyzing the effect of the mixture of various substrates on the emergence and initial development of açaí seedlings, it was found that the soil + Provaso ${ }^{\circledR}$ mixture was the one that provided the best result of the shoot length. These results are in contrast to those found by Costa et al. (2012) when they evaluated the Bioplant ${ }^{\circledR}$ substrates, terra preta + humus; black earth + humus + coconut fiber and black earth + filter cake + humus, in the production of lettuce seedlings, in which the best result of aerial part length was added from cultivation in Bioplant ${ }^{\mathbb{R}}$.

Table 3 shows the results of the percentage of shoot emission for the factors evaluated. The evaluated containers showed no statistical difference, that is, both the volume of 280 and $500 \mathrm{ml}$ proved to be viable, the substrate composed of Provaso $^{\circledR}+$ soil, showed $100 \%$ sprouting emission, corroborating with the results of emergency percentage, emergency speed index and average emergency time, which showed greater emphasis on the substrate Provaso $^{\circledR}+$ soil.

Table 3. Sprout emission percentage (\% EB) of Physalis peruviana L. seedlings according to different volumes of containers and substrates

\begin{tabular}{lc}
\hline Sprout emission percentage & \\
\hline Container $(\mathrm{ml})$ & \\
280 & $91.65 \mathrm{a}$ \\
500 & $93.73 \mathrm{a}$ \\
\hline Substrate & $85.38 \mathrm{~b}$ \\
Bioplant & $100.00 \mathrm{a}$ \\
Provaso + soil & 10.51 \\
\hline CV $(\%)$ & \\
\hline
\end{tabular}

Note. Averages followed by the same lowercase letter in the columns, do not differ statistically from each other, by the Tukey test at the level of $1 \%$ probability. 
Santos et al. (2012), in a work testing the vegetative propagation of passion fruit cuttings in different containers and commercial substrates, observed that the $573 \mathrm{~cm}^{3}$ container obtained a higher percentage of cuttings with buds than the $50 \mathrm{~cm}^{3}$ and $280 \mathrm{~cm}^{3}$ containers, associated with the commercial substrate Vivatto ${ }^{\circledR}$, which provided a better result than the Bioplant ${ }^{\mathbb{B}}$ substrate. This work confirms what has been demonstrated in the present experiment, that the bigger the substrate the better the seedling performance.

In the present study, it was evident that, for all the variables studied, the 280 and $500 \mathrm{ml}$ containers stood out, however, aiming at a better cost benefit, it is recommended to use the $280 \mathrm{ml}$ containers because in addition to occupying a smaller space in the nursery, enables more substrate savings. In general, the Provaso ${ }^{\circledR}+$ soil substrate $^{2}$ was the one that stood out the most, several factors that contributed to this fact. Lima et al. (2006) Relating chicken litter to one of the components present in Provaso ${ }^{\circledR}$ proved to be an active chemical source, composing a good substrate always associated with a material that offers good characteristics, such as compost for vegetable pie (castor, cotton, etc.) of natural decomposition of organic matter sources and which is also present in the Provaso ${ }^{\circledR}$ substrate.

This result is very relevant for producers who are interested in starting the production of the crop in the northern region of Espírito Santo, since this substrate is from the region, being easily found in agricultural products stores. The information of which volume is more suitable for the development of seedlings facilitates the management, due to the little technical information available regarding the culture of fisális. Thus, it demonstrates the real need for studies that evaluate not only the substrate and the container, but all the factors involved in the production of crop seedlings, in order to have an exact notion of the plant's development in the initial phase and, if the producer wants to invest in another form of propagation, such as the mini-cutting approach in this experiment.

\section{Conclusion}

For better emergence and emission of shoots of Physalis peruviana L., a volume of $280 \mathrm{ml}$ is recommended, combined with the substrate Provaso $^{\circledR}+$ soil.

\section{Acknowledgements}

To FAPES (Espírito Santo Research Support Foundation) for the confidence in approving and contemplating my work done with fisális with a support and incentive scholarship.

\section{References}

Alfenas, A. C., Zauza, E. A. V., Mafia, R. G., \& Assis, T. F. (2009). Cloning and eucalyptus diseases (pp. 500-504). Viçosa, MG: Ed da UF.

Almeida, R. N., Ferraz, D. R, Silva, A. S., Cunha, E. G., Vieira, J. C., Souza, T. S., \& Berilli, S. S. (2017). Use of tannery sludge in addition to the commercial substrate in the production of biquinho pepper seedlings. Revista Scientia Agraria, 18(1), 20-33. https://doi.org/10.5380/rsa.v18i1.49914

Bioplant. (2020). Substrates with the quality you need. Retrieved August 26, 2020, from http://www.bioplant. com.br

Brasil, Ministry of Agriculture, Livestock and Supply. (2009). Rules for seed analysis (p. 399). Brasília: MAPA/ACS.

Carvalho, R. P. de, Cruz, M. do C. M., \& Martins, L. M. (2013). Frequência de irrigação utilizando polímero hidroabsorvente na produção de mudas de maracujazeiro amarelo. Revista Brasileira de Fruticultura, 35(2). https://doi.org/10.1590/S0100-29452013000200022

Costa, E., Santos, L. C. R., Carvalho, C., Leal, P. A. M., \& Gomes, V. A. (2011). Volumes of commercial substrates, soil and organic compost affecting the formation of yellow passion fruit seedlings in different growing environments. Revista Ceres, 58(2), 216-222. https://doi.org/10.1590/S0034-737X2011000200013

Costa, K. D. da S., Carvalho, I. D. E., Ferreira, P. V., Silva, J., \& Teixeira, J. S. (2012). Evaluation of alternative substrates for the production of lettuce seedlings. Revista Verde, 7(5), 58-62.

Fischer, G., Almanza-Merchán, P. J., \& Miranda, D. (2014). Importance and cultivation of the Cape Gooseberry (Physalis peruviana L.). Revista Brasileira de Fruticultura, 36(1), 01-15. https://doi.org/10.1590/ 0100-2945-441/13

Ianckievicz, A., Takahashi, H. W., Fregonezi, G. A. F., \& Rodini, F. K. (2013). Production and development of the Physalis L. culture submitted to different levels of electrical conductivity of the nutrient solution. Ciência Rural, 43, 438-444. https://doi.org/10.1590/S0103-84782013000300010 
Kuhn, P. R., Kulczynski, S. M., Bellé, C., Koch, F., \& Werner, C. J. (2012). Production of fisalis seedlings (Physalis peruviana) from seeds of green and ripe fruits submitted to different substrates. Enciclopédia Biosfera, 8(5), 1378-1385. https://doi.org/10.1126/science.1215904

Lima, R. L. S., Severino, L. S., Silva, M. I. L., Vale, L. S., \& Beltrão, N. E. M. (2006). Volume of containers and composition of substrates for the production of castor bean seedlings. Ciência e Agrotecnogia, 30(3), 480-486. https://doi.org/10.1590/S1413-70542006000300014

Mendonça, M., Melo, J. K. H., Mendonça, L. F. M., Leite, G. A., \& Pereira, E. C. (2014). Evaluation of different substrates in the production of tamarind rootstock. Revista Caatinga, 27(1), 60-66.

Muniz, J., Kretzschmar, A. A., Rufato, J., Pelizza, R., Rufato, A. R., \& Macedo, T. F. (2014). General aspects of the physalis culture. Ciência Rural, 44(6), 964-970. https://doi.org/10.1590/S0103-84782014005000006

Muniz, J., Molina, A. R., \& Muniz, J. (2015). Physalis: Productive and economic outlook in Brazil. Horticultura Brasileira, 33(2). https://doi.org/10.1590/S0102-053620150000200023

Oliveira, G. H., Casaroli, D., Fagan, E. B., Silva, J. O., Soares, L. H., \& Sousa, M. C. (2011). Growth evaluation of tomato seedlings in different types of commercial trays. Cerrado Agrociências, 2, 84-90. https://doi.org/ 10.14295/cs.v9i1.1313

Paixão, M. V. S., Júnior, H. P. de, Hoffay, A. C. N., Mônico, A. F., Oliveira , E. M. de, \& Grobério, R. B. C. (2019). Probable fertilizer mixed with the substrate in the emergence and initial development of açaí palm seedlings. Brazilian Jornal of Animal and Environmental Research, 2(3), 975-981.

Provaso. (2020). Class A organic fertilizer $25 \mathrm{~kg}$. Retrieved August 26, 2020, from https://www.agrosolo.com.br/ provaso-fertilizante-organico-classe-a- $25 \mathrm{~kg}$

Puente, L. A. (2011). Physalis peruviana L., the multiple properties of a highly functional fruit: A review. Food Research International, 44, 1733-1740. https://doi.org/10.1016/j.foodres.2010.09.034

Rufato, L., Rufato, A. R., Schelemper, C., Lima, C. S. M., Kretzschamr, A. A. (2008). Technical aspects of Physalis culture (p. 101). Lages: CAV/UDESC; Pelotas: UFPel.

Santos, A. S. (2019). Seed germination and seedling production of Physalis peruviana L. under salt stress (108f., Dissertation (Master's), Federal University of Campina Grande, Pombal, PB). Retrieved from http://dspace.sti.ufcg.edu.br:8080/jspui/handle/riufcg/7268

Santos, J. L., Matsumoto, S. N., Arêde, L. O., Luz, I. S., \& Viana, A. E. S. (2012). Vegetative propagation of cuttings of Passiflora cincinnata Mast. in different containers and commercial substrates. Revista Brasileira de Fruticultura, 34(2), 581-588. https://doi.org/10.1590/S0100-29452012000200033

Santos, P. L. F., Silva, O. N. M., Paixão, A. P., \& Castilho, R. M. M. (2017). Germination and development of cherry tomato seedlings on different substrates. Tecnologia \& Ciência Agropecuária, 11(5), 41-45.

Sbrussi C. A. G., Zucarelli, C., Prando, A. M., \& Silva, B. V. A. B. (2014). Maturation stages of fruit development and physiological seed quality in Physalis peruviana. Revista Ciência Agronômica, 45(3), 543-549. https://doi.org/10.1590/S1806-66902014000300015

Silva, F. A. Z., \& Azevedo, C. A. V. (2016). The Assistat software version 7.7 and its use in the analysis of experimental data. African Journal of Agricultural Research, 11(39), 3733-3740. https://doi.org/10.5897/ AJAR2016.1522

Vargas-Ponce, O., Martinez, J. S., Tavares, M. P. Z., \& Mares, L. E. V. (2017). Traditional management of a small-scale crop of Physalis angulata in Western Mexico. Genetic Resources and Crop Evolution, 63, 1383-1395. https://doi.org/10.1007/s10722-015-0326-3

Xavier, A., Wendling, I., \& Silva, R. L. (2013). Clonal forestry: Principles and techniques (p. 379). Viçosa, MG: UFV.

\section{Copyrights}

Copyright for this article is retained by the author(s), with first publication rights granted to the journal.

This is an open-access article distributed under the terms and conditions of the Creative Commons Attribution license (http://creativecommons.org/licenses/by/4.0/). 